\title{
Influence of mowing measures on carabid beetle fauna (Coleoptera: Carabidae) in a post-agricultural area
}

\author{
AXEL SCHWERK \\ MAGDALENA A. KITKA \\ Laboratory for Evaluation and Assessment \\ of Natural Resources \\ Warsaw University of Life Sciences - SGGW \\ Nowoursynowska Street 166, 02-787 Warsaw, Poland \\ Correspondence: \\ Axel Schwerk \\ E-mail:aschwerk@yahoo.de
}

\section{Nonstandard abbreviations}

MIB: Mean individual biomass of Carabidae

Keywords: $\mathrm{BACl}$, fallow land, MIB, agricultural practices, management

Received January 14, 2016.

Revised May 31, 2016.

Accepted May 31, 2016

\section{Abstract}

Background and purpose: Some agricultural practices are considered to be useful tools in biodiversity conservation. Therefore, carabid beetles were collected on post-agricultural fallow land in Western Poland in order to study the impact of mowing treatment.

Materials and Methods: Following a "before-after-control-impact" (BACI) study design over the period of two years $(2013$ - 2014), standard arrays of pitfall traps were installed on six study sites, of which three were treated by mowing at the beginning of July in the second year of study. The influence of this treatment was analysed statistically with respect to the most frequently collected species, selected ecological traits, as well as the mean individual biomass of the carabid assemblages (MIB). Additionally, Non-metric Multidimensional Scaling (NMDS) was carried out.

Results: A total of 1995 individuals belonging to 40 species were collected, with species numbers ranging from 11 to 21 and numbers of individuals ranging from 76 to 278 in the samples. Although some species reacted significantly to the mowing treatment and numbers of individuals of forest species significantly decreased on the treatment sites, in general rather weak effects were observed as a result of the mowing measures. The weak effects of the mowing measures may be explained by the low cutting intensity (only once a year) and differences in environmental conditions between the years of study.

Conclusions: The results of the study are assumed to be useful in the context of planning mowing measures in order to conserve biological diversity. Yet, the results also underline the importance of long-term studies.

\section{INTRODUCTION}

Tntensification of agriculture is assessed to be a main driver of loss in biological diversity $(1,2,3,4)$. To counteract this tendency, different stategies have been proposed. Positive effects have been proven for the establishement of botanically diverse field margin strips (5, 6). Setting aside agricultural fields has been considered as a measure to enhance biological diversity, too. However, while several studies provide evidence for positive influence of fallow ground (e.g. 7, 8, 9, 10), some studies also report on its negative impact on biodiversity (e.g. 11). According to Burel and Baudry (12), predictions of the effects of land abandonment are difficult and opportunities offered by land abandonment differ with regard to the species. In contrast, various traditional agricultural practices are considered to be useful tools in biodiversity conservation (e.g. 13) and have been integrated into agri-environmental schemes and nature-reserve management (e.g. 14). Amongst such practices are grazing and mowing, the latter as a surrogate for grazing $(13,14)$. These mea- 
sures influence the structure of grassland vegetation, which is a product of the interplay between successional processes and management. The structure of grassland vegetation, however, is crucial for maintaining arthropod diversity (13).

Among arthropods, carabid beetles have an important position in agricultural systems, such as biological control agents on agricultural pests (15) or seed predators of weeds $(16,17)$. Carabids react to management practices in grassland habitats (18) and have a potential for indicating environmental variation (19). An approach often used is to study changes in ecological traits of the carabid assemblages, e.g. the reproduction period or habitat preferences (19). The mean individual biomass of Carabidae (MIB) has been proposed as an indicator of the stage of succession of a habitat $(20,21)$. This method assumes an ongoing process of succession with which the MIB of carabids increases. MIB was established in order to assesss forest ecosystems in Poland (20). However, this method has also been used in the context of assessing recovery processes in Mediterranean ecosystems or studying forest patch isolation $(22,23)$. In addition, MIB has been shown to react sensitively to management strategies on post-agricultural areas (24).

In order to improve our knowledge about the impact of mowing measures on carabid beetles we initiated the presented study in a research area of post-agricultural land in Western Poland. The impact of mowing measures on carabid beetles in this area has been studied before on different study plots (e.g. 24, 25). However, the presented paper is the first study using a „before-after-control-impact" (BACI) design (26), applying mowing to the treatment sites in the second year of the study. By comparing carabid data on treatment sites and control sites we wanted to test the following hypotheses:

1) Species react to the mowing measures, expressed as significant differences in catch numbers on the treatment sites, but not on the control sites, between the first and the second year of study.

2) Numbers of individuals of species characterised by specific ecological traits will change significantly on the treatment sites, but not on the control sites.

3) MIB as an indicator of the stage of succession decreases significantly on the treatment sites, but not on the control sites, from the first to the second year of study.

4) Carabid assemblages of mown sites differ from assemblages of unmown sites.

\section{MATERIAL AND METHODS}

\section{Study sites and field methods}

For our study, we selected the research area „Krzywda,” an area of more than 170 ha including agricultural fields, abandoned farmland, wet habitats and forest sites (27). The study was carried out in 2013 - 2014 on post-agricultural fallow land abandoned from crop production for 21 years in 2013 (27). It followed a „before-after-controlimpact" (BACI) design with three treatment sites and

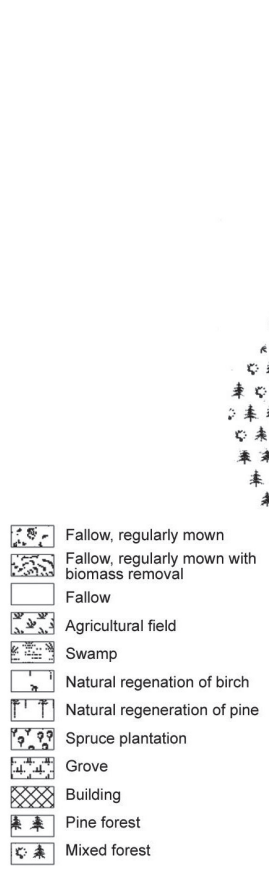

a

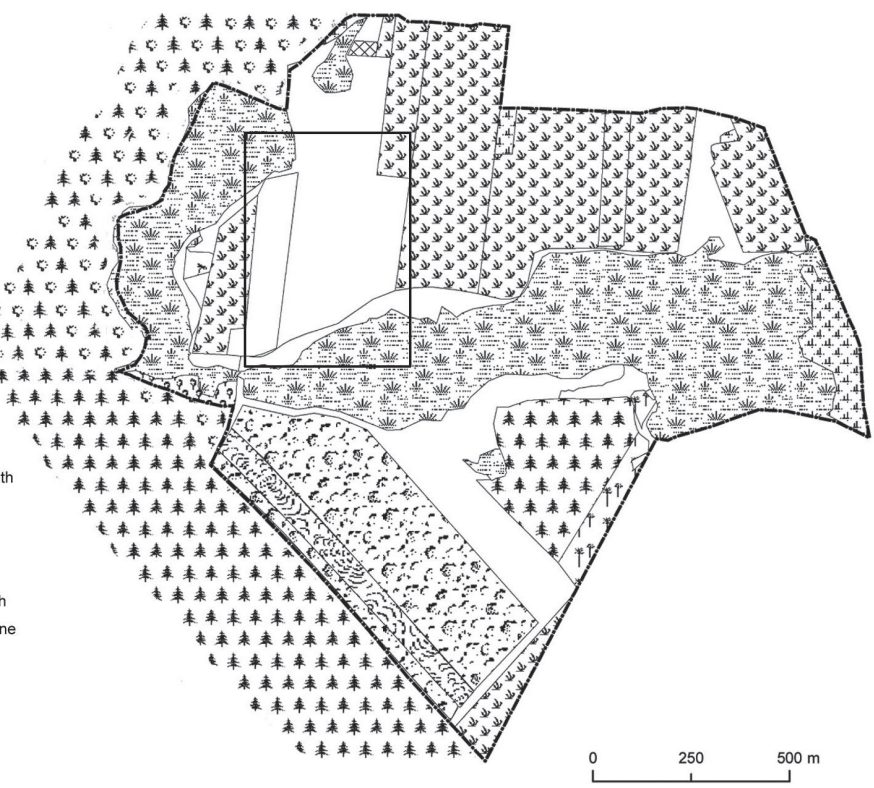

b

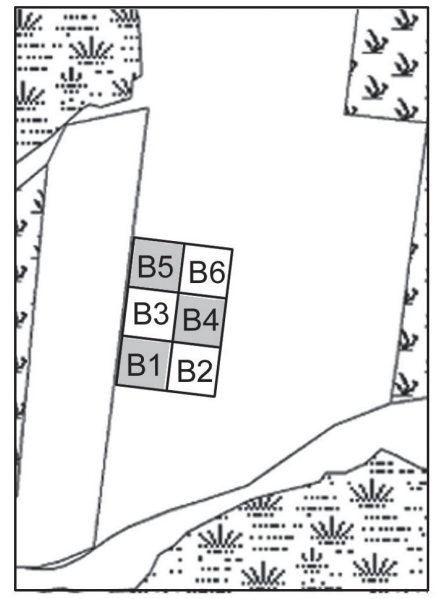

Figure 1: Scheme of the research area "Krzywda“ (a) with the location of study sites B1-B6 (b). Study sites mown in 2014 are indicated by grey colour. 
three control sites. Thus, six study sites $(\mathrm{B} 1-\mathrm{B} 6)$ of $50 \mathrm{~m}$ x 50 m were established, three of which (B1, B4, B5) were mown with biomass removal on July 5 th, 2014, while the remaining three (B2, B3, B6) were left untreated (Fig. 1).

Carabids were collected using pitfall traps from midMay to mid-September. Traps were glass jars topped with a funnel (upper diameter of about $10 \mathrm{~cm}$ ) set flush with the soil surface. A roof was suspended a few $\mathrm{cm}$ above the funnel and $50 \mathrm{ml}$ ethylene glycol was used as a killing agent and preservative. The traps were checked every 2-3 weeks for proper functioning. If necessary, ethylene glycol was refilled. Three traps (distance $3 \mathrm{~m}$ ) were installed in the center of each study site. The results of the three traps were pooled to one sample for each study site.

All collected specimens were determined to the species level. Nomenclature follows Freude et al. (28).

\section{Statistical methods}

For each species, the total number of individuals per study site was calculated.

The recorded species were classified with respect to their habitat preferences (species characteristic for open habitats, eurytopic species, species characteristic for forests) and breeding type (spring breeders, autumn breeders) based on the literature $(28,29,30,31,32,33,34)$. For each of these ecological traits, the total number of collected individuals per study site was calculated.

For each study site, we also computed MIB values as an indicator of succession. MIB is calculated by summing up the biomass of all carabids in a sample and subsequently dividing it by the number of specimens caught. Biomass values for the species recorded are those cited by Szyszko (20) or obtained using the term by Szyszko (35) which describes the relationship between the body length of a single carabid individual $(x)$ and its biomass $(y)$ :

$$
\ln y=-8.92804283+2.55549621 \times \ln x
$$

For further statistical analysis, we selected species, which were collected with at least 150 individuals, and looked at the ecological traits (species characteristic for open habitats, eurytopic species, species characteristic for forests, spring breeders, autumn breeders) and MIB values calculated for the study sites. Differences in the numbers of individuals of the selected species, numbers of individuals per ecological trait, and MIB values between 2013 and 2014 on the treatment sites and the control sites respectively were tested using the Mann-Whitney $U$ test (36).

We carried out Non-metric Multidimensional Scaling (NMDS) using PAST v. 2.17c (37) in order to analyse differences between the carabid assemblages. Abundance data of the collected species per study site were $\log (1+\mathrm{x})$ transformed and the Bray-Curtis index was used as the distance between assemblages.
Tab. 1: Type of treatment, number of species, and number of individuals per study site in 2013 and 2014.

\begin{tabular}{|cccc|}
\hline Study site & Site type/treatment & Species & Individuals \\
\hline \multicolumn{4}{c}{2013} \\
\hline B1 & Treatment site/unmown & 20 & 182 \\
B2 & Control site/unmown & 17 & 232 \\
B3 & Control site/unmown & 17 & 151 \\
B4 & Treatment site/unmown & 17 & 235 \\
B5 & Treatment site/unmown & 21 & 160 \\
B6 & Control site/unmown & 16 & 82 \\
\hline & 2014 & & \\
\hline B1 & Treatment site/mown & 17 & 141 \\
B2 & Control site/unmown & 18 & 158 \\
B3 & Control site/unmown & 13 & 76 \\
B4 & Treatment site/mown & 11 & 147 \\
B5 & Treatment site/mown & 21 & 153 \\
B6 & Control site/unmown & 18 & 278 \\
\hline
\end{tabular}

\section{RESULTS}

A total of 1995 individuals belonging to 40 species (Appendix 1) were collected (Tab. 1). Species collected with at least 150 individuals were Harpalus rufipes (309), Harpalus tardus (238), Harpalus rubripes (220), Calathus erratus (163), Amara aenea (162), and Pterostichus niger (153).

Among the six most dominant species only Pterostichus niger and Harpalus rubripes reacted to mowing the treatment sites with significant changes in catch numbers. Both species showed significant lower numbers in 2014 as compared to 2013. For none of the studied species a significant difference in catch numbers were observed on the control plots between 2013 and 2014 (Tab. 2). Noteworthy, with the exception of Amara aenea for all species the same tendency was observed on treatment and control sites; i.e. if the mean number increased on treatment sites from 2013 to 2014 then it also increased on the control sites and vice versa. None of the studied ecological traits (species characteristic for open habitats, eurytopic species, species characteristic for forests, spring breeders, autumn breeders) displayed a significant difference between the years of study on the control sites, but on the treatment sites the number of individuals of forest species was significantly lower in 2014 (Tab. 2). MIB values did not decrease significantly as a result of mowing. However, with a decrease in MIB observed on both the treatment and the control sites, this decrease was more pronounced on the treatment sites (Tab. 2).

NMDS (Fig. 2) did not reveal a clear separation of the samples collected on mown study sites (B1, B4, B5 in 2014) from the samples collected on unmown study sites. The stress for the first two ordination axes was low (0.1548). 
Tab. 2: Mean values and standard error (SE) of catch sizes of the most frequently collected species, of numbers of individuals belonging to certain ecological groups, and of MIB values on the study sites in 2013 and 2014. Significance refers to comparisons between the respective samples using the Mann-Whitney U test.

\begin{tabular}{|c|c|c|c|}
\hline Species - year & $\mathrm{n}$ & Mean \pm SE & Significance \\
\hline \multicolumn{4}{|c|}{ Treatment sites } \\
\hline H. rufipes -2013 & 3 & $40.00 \pm 5.51$ & n.s. \\
\hline H. rufipes -2014 & 3 & $23.33 \pm 4.41$ & \\
\hline H. tardus -2013 & 3 & $21.33 \pm 14.08$ & n.s. \\
\hline H. tardus -2014 & 3 & $11.67 \pm 4.70$ & \\
\hline H. rubripes -2013 & 3 & $28.0 \pm 1.15$ & $\mathrm{p}<0.05$ \\
\hline H. rubripes -2014 & 3 & $11.67 \pm 4.98$ & \\
\hline C. erratus -2013 & 3 & $15.33 \pm 2.19$ & n.s. \\
\hline C. erratus - 2014 & 3 & $18.00 \pm 8.62$ & \\
\hline A. aenea - 2013 & 3 & $2.33 \pm 1.86$ & n.s. \\
\hline A. aenea -2014 & 3 & $1.33 \pm 1.33$ & \\
\hline Pt. niger - 2013 & 3 & $15.00 \pm 1.15$ & $\mathrm{p}<0.05$ \\
\hline Pt. niger- 2014 & 3 & $6.67 \pm 2.19$ & \\
\hline Open habitats - 2013 & 3 & $112.33 \pm 5.17$ & n.s. \\
\hline Open habitats - 2014 & 3 & $89.33 \pm 11.62$ & \\
\hline Eurytopic - 2013 & 3 & $64.33 \pm 20.37$ & n.s. \\
\hline Eurytopic - 2014 & 3 & $51.00 \pm 12.34$ & \\
\hline Forests - 2013 & 3 & $15.67 \pm 1.45$ & $\mathrm{p}<0.05$ \\
\hline Forests -2014 & 3 & $6.67 \pm 2.19$ & \\
\hline Spring - 2013 & 3 & $94.00 \pm 21.70$ & n.s. \\
\hline Spring - 2014 & 3 & $70.67 \pm 17.82$ & \\
\hline Autumn - 2013 & 3 & $98.33 \pm 3.67$ & n.s. \\
\hline Autumn - 2014 & 3 & $76.33 \pm 20.67$ & \\
\hline MIB - 2013 & 3 & $78.53 \pm 5.66$ & n.s. \\
\hline MIB - 2014 & 3 & $63.90 \pm 8.36$ & \\
\hline \multicolumn{4}{|c|}{ Control sites } \\
\hline H. rufipes -2013 & 3 & $26.33 \pm 8.69$ & n.s. \\
\hline H. rufipes - 2014 & 3 & $13.33 \pm 5.36$ & \\
\hline H. tardus -2013 & 3 & $27.67 \pm 17.29$ & n.s. \\
\hline H. tardus -2014 & 3 & $18.67 \pm 6.94$ & \\
\hline H. rubripes - 2013 & 3 & $22.00 \pm 6.11$ & n.s. \\
\hline H. rubripes -2014 & 3 & $11.67 \pm 3.53$ & \\
\hline C. erratus - 2013 & 3 & $8.00 \pm 3.79$ & n.s. \\
\hline C. erratus -2014 & 3 & $13.00 \pm 12.00$ & \\
\hline A. aenea- 2013 & 3 & $10.00 \pm 5.86$ & n.s. \\
\hline A. aenea-2014 & 3 & $40.33 \pm 34.89$ & \\
\hline Pt. niger - 2013 & 3 & $17.00 \pm 14.57$ & n.s. \\
\hline Pt. niger - 2014 & 3 & $12.33 \pm 7.22$ & \\
\hline Open habitats - 2013 & 3 & $88.33 \pm 15.21$ & n.s. \\
\hline Open habitats - 2014 & 3 & $108.33 \pm 54.39$ & \\
\hline Eurytopic - 2013 & 3 & $49.33 \pm 20.63$ & n.s. \\
\hline Eurytopic - 2014 & 3 & $49.67 \pm 13.35$ & \\
\hline Forests - 2013 & 3 & $17.33 \pm 14.44$ & n.s. \\
\hline Forests -2014 & 3 & $12.67 \pm 7.51$ & \\
\hline Spring - 2013 & 3 & $93.00 \pm 25.36$ & n.s. \\
\hline Spring - 2014 & 3 & $117.67 \pm 39.91$ & \\
\hline Autumn - 2013 & 3 & $62.00 \pm 19.00$ & n.s. \\
\hline Autumn - 2014 & 3 & $53.00 \pm 18.90$ & \\
\hline MIB - 2013 & 3 & $67.53 \pm 11.81$ & n.s. \\
\hline MIB - 2014 & 3 & $59.93 \pm 9.93$ & \\
\hline
\end{tabular}




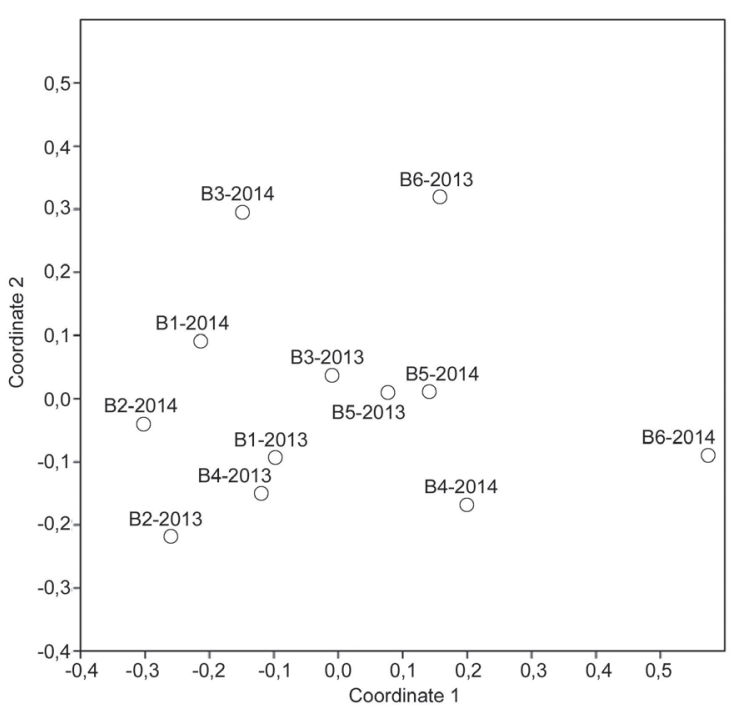

Figure 2. Ordination plot based on Non-metric Multidimensional Scaling (NMDS); study sites B1 - B6, year of study.

\section{DIsCusSION}

Even if some species did show significant changes in catch numbers (hyp. 1), generally only weak effects of the mowing measures were detected. While numbers of individuals of forest species significantly decreased on the treatment sites (hyp. 2) MIB did not decrease significantly after mowing (hyp. 3). Accordingly, when using NMDS, the samples from mown study sites were not explicitely separated from the samples of unmown sites (hyp. 4).

The weak effects of the mowing measures may be explained by the assumption that mowing only once at the beginning of July was not sufficient to significantly overcome environmental characteristics of the study sites. Pterostichus niger is known to be active in autumn (e.g. 30, 33) and Harpalus rubripes is mentioned to breed both in spring and autumn (33). Larsson (29) describes it as „autumn species (possibly unstable)." This may indicate that species breeding later in the year were particularly affected by the mowing measures. However, the results of analysing the ecological traits indicate that forest species reacted most sensitively (significant difference with respect to forest species on the treatment sites, Tab. 2).

Since the basic trends between the years were the same for almost all dominant species on the treatment and control sites, differences in environmental conditions between the study years might have had an influence on the formation of carabid assemblages, too. This may to some degree disguise the effects caused by mowing. According to den Boer (e.g. 38, 39), such stochastic processes will necessarily lead to density fluctuations of individual species on fixed sampling plots. As a conclusion, long-term sampling under varying conditions is recommended to precisely identify the indicator potential of individual species (19).
Intensification of mowing measures (e.g. mowing twice a year) may lead to more pronounced differences. Kitahara et al. (40), studying grasslands being mown once up to $3-4$ times, observed a highly significant decrease in butterfly species numbers with increasing disturbance intensity. However, the highest carabid diversity was observed for medium management intensity in grasslands managed with different intensities (41). Accordingly, Mazalová et al. (42) reported the highest species richness of butterflies and beetles, at a larger time scale, in grasslands mown once a year, especially when applying a combined regime of mowing and grazing. According to Morris (13), Coleoptera in general are more robust to cutting measures than other arthropods (i.e. Auchenorrhyncha).

The results of this study are assumed to be useful when planning mowing measures in order to conserve biological diversity. Please note that the effect of cutting treatment may vary and therefore the timing and frequency of this management method should be varied (13). Mowing should also be put into context with other agricultural practices which might influence species assemblages, e.g. soil tillage $(9,43)$. Our results underline the importance of long-term studies in order to fully understand the reaction of individual species to management measures and to define their potential as ecological indicators.

\section{ACKNOWLEDGEMENTS}

The authors thank two anonymous reviewers and Lucija Šerić Jelaska for valuable comments on the manuscript and K. Hannig for confirming the identification of beetles. This paper is communication No. 477 of the Laboratory of Evaluation and Assessment of Natural Resources, Warsaw University of Life Sciences - SGGW.

\section{REFERENCES}

1. MATSON P A, PARTON W J, POWER A G, SWIFT M J 1997 Agricultural intensification and ecosystem properties. Science 277: 504-509 http://dx.doi.org/10.1126/science.277.5325.504

2. KREBS J R, WILSONJ D, BRADBURY R B, SIRIWARDENA G M 1999 The second silent spring? Nature 400: 611-612

3. DONALD P F, SANDERSON F J, BURFIELD IJ , VAN BOMMEL F P J 2006 Further evidence of continent-wide impacts of agricultural intensification on European farmland birds, 1990 2000. Agric Ecosyst Environ 116: 189-196 http://dx.doi.org/10.1016/j.agee.2006.02.007

4. WATT A D, BRADSHAW R H W, YOUNG J, ALARD D, BOLGER T, CHAMBERLAIN D, FERNÁNDEZ-GONZÁLEZ F, FULLER P, GURREA P, HENLE K,JOHNSON R, KORSÓ Z, LAVELLE P, NIEMELÄJ, NOWICKI P, REBANEM, SCHEIDEGGER C, SOUSA J P, VAN SWAAYC, VANBERGEN A 2007 Trends in biodiversity in Europe and the Impact of land-use change. Issues Environ Sci Technol 25: 135-160

5. THOMAS C F G, MARSHALL E J P 1999 Arthropod abundance and diversity in differently vegetated margins of arable Fields. Agric Ecosyst Environ 72: 131-144 http://dx.doi.org/10.1016/S0167-8809(98)00169-8 
6. SMITH J, POTTS S G, WOODCOCK B A, EGGLETON P 2008 Can arable field margins be managed to enhance their biodiversity, conservation and functional value for soil macrofauna? J Appl Ecol 45: 269-278

7. JEDICKE E 1989 Brachland als Lebensraum. Buchverlag Otto Mayer, Ravensburg, p 127

8. DESENDER K, BOSMANS R 1998 Ground beetles (Coleoptera, Carabidae) on set-aside fields in the Campine region and their importance for nature conservation in Flanders (Belgium). Biodivers Conserv 7: 1485-1493

http://dx.doi.org/10.1023/A:1008813102410

9. HOLLAND J M, LUFF M L 2000 The effects of agricultural practices on Carabidae in temperate agroecosystems. Integr Pest Manag Rev 5: 109-129 http://dx.doi.org/10.1023/A:1009619309424

10. HOLLAND J, BIRKETT T, BEGBIE M, SOUTHWAY $S$, THOMAS C F G 2003 The spatial dynamics of predatory arthropods and the importance of crop and adjacent margin habitats. IOBC wprs Bull 26: 65-70

11. REY BENAYAS J M,MARTINS A, NICOLAU JM, SCHULZ J J 2007Abandonment of agricultural land: an overview of drivers and consequences. CAB Rev: Perspect Agric Vet Sci Nutr Nat Resour 2: 1-14

12. BUREL F, BAUDRY J 1995 Species biodiversity in changing agricultural landscapes: A case study in the Pays d'Auge, France. Agric Ecosyst Environ 55: 193-200

http://dx.doi.org/10.1016/0167-8809(95)00614-X

13. MORRIS M G 2000 The effects of structure and its dynamics on the ecology and conservation of arthropods in British grasslands. Biol Conserv 95: 129-142 http://dx.doi.org/10.1016/S0006-3207(00)00028-8

14. HABER N, FEHRENBACH M 2004 MEKA and LPR -steps towards an effective integration of land use and nature conservation. In: Dieterich M, van der Straaten J (eds) Cultural landscapes and land use. Kluwer Academic Publishers, The Netherlands, p 163-181 http://dx.doi.org/10.1007/1-4020-2105-4_10

15. HUMPHREYS I C, MOWAT, D J 1994 Effects of some organic treatments on predators (Coleoptera: Carabidae) of Cabbage Root Fly, Delia radicum (L.) (Diptera: Anthomyiidae), and on alternative prey species. Pedobiol 38: 513-518

16. SASKA P 2008 Composition of weed community determines carabid assemblage. In: Penev L, Erwin T, Assmann T (eds) Back to the roots and back to the future. Towards a new synthesis between taxonomic, ecological and biogeographical approaches in Carabidology. Pensoft Publishers, Sofia, Moscow, p 339-351

17. PETIT S, BOURSAULT A, BOHAN DA 2014 Weedseed choice by carabid beetles (Coleoptera: Carabidae): Linking field measurements with laboratory diet assessments. Eur J Entomol 111: 615620

18. RAINIO J, NIEMELÄ J 2003 Ground beetles (Coleoptera: Carabidae) as bioindicators. Biodivers Conserv 12: 487-506 http://dx.doi.org/10.1023/A:1022412617568

19. KOIVULA M J2011 Useful model organisms, indicators, or both? Ground beetles (Coleoptera, Carabidae) reflecting environmental conditions. ZooKeys 100: 287-317 http://dx.doi.org/10.3897/zookeys.100.1533

20. SZYSZKO J 1990 Planning of prophylaxis in threatened pine forest biocoenoses based on an analysis of the fauna of epigeic Carabidae. Warsaw Agricultural University Press, Warsaw, p 96

21. SZYSZKO J, VERMEULEN H J W, KLIMASZEWSKI K, ABS M, SCHWERK A 2000 Mean Individual Biomass (MIB) of Carabidae as an indicator of the state of the environment. $I n$ : Brandmayr P, Lövei G, Zetto Brandmayr T, Casale A, Vigna Taglianti A (eds) Natural history and applied ecology of carabid beetles. Pensoft Publishers, Sofia, Moscow, p 288-294
22. CÁRDENAS A M \& HIDALGO J M 2007 Application of the mean individual biomass (MIB) of ground beetles (Coleoptera, Carabidae) to assess the recovery process of the Guadiamar Green Corridor (southern Iberian Peninsula). Biodivers Conserv 16 4131-4146 http://dx.doi.org/10.1007/s10531-007-9211-5

23. ŠERIĆ JELASKA L, DURBEŠIĆ P 2009 Comparison of the body size and wing form of carabid species (Coleoptera: Carabidae) between isolated and continuous forest habitats. Ann Soc Fntomol Fr (n.s.) 45: 327-338

24. SCHWERKA, SZYSZKO J 2009 Distribution and spatial preferences of carabid species (Coleoptera: Carabidae) in a forest-field landscape in Poland. Baltic J Coleopterol 9: 5-15

25. BŁASZKIEWICZ M, SCHWERK A 2013 Carabid beetle (Coleoptera: Carabidae) diversity in agricultural and post-agricultural areas in relation to the surrounding habitats. Baltic J Coleopterol 13: $15-26$

26. UNDERWOOD A J 1991 Experimental designs for detecting human environmental impactson temporal variations in natural populations. Aust J Mar Freshwater Res 42: 569-587 http://dx.doi.org/10.1071/MF9910569

27. DYMITRYSZYN I, SZYSZKO J, RYLKE J (eds) 2013 Field methods of evaluation and assessment of natural resources. Wydawnictwo SGGW, Warsaw, p 264

28. FREUDE H, HARDE K-W, LOHSE G A, KLAUSNITZER B 2004 Die Käfer Mitteleuropas. Bd. 2, Adephaga 1, Carabidae (Laufkäfer). 2. (erweiterte) Aul., Spektrum, Heidelberg/Berlin, p 521

29. LARSSON S G 1939 Entwicklungstypen und Entwicklungszeiten der dänischen Carabiden. Entomol Medd 20: 277-562

30. LINDROTH C H 1945 Die Fennoscandischen Carabidae: I Spezieller Teil. Göteborg, p 709

31. BURAKOWSKI B, MROCZKOWSKI M, STEFAŃSKA J 1973 Katalog fauny Polski (Catalogus faunae Poloniae). Część XXIII, tom 2. Chrząszcze (Coloeptera). Biegaczowate (Carabidae), część 1. Państwowe Wydawnictwo Naukowe, Warszawa, p 233

32. BURAKOWSKI B, MROCZKOWSKI M, STEFAŃSKA J 1974 Katalog fauny Polski (Catalogus faunae Poloniae). Część XXIII, tom 3. Chrząsccze (Coloeptera). Biegaczowate (Carabidae), część 2. Państwowe Wydawnictwo Naukowe, Warszawa, p 430

33. LINDROTH C H 1986 The Carabidae (Coleoptera) of Fennoscandia and Denmark. Fauna Entomologica Scandinavica. Volume 15, Part II. Scandinavian Science Press, Ltd. Leiden, p 497

34. HURKA K 1996 Carabidae of Czech and Slowak Republics. Kabournek, Zlin, p 565

35. SZYSZKO J 1983 Methods of macrofauna investigations. In: Szujecki A, Szyzsko J, Mazur S, Perliński S (eds): The process of forest soil macrofauna formation after afforestation of farmland. Warsaw Agricultural University Press, Warsaw, p 10-16

36. SACHS L 1984 Angewandte Statistik: Anwendung statistischer Methoden. 6th ed. Springer, Berlin, Heidelberg, New York, Tokyo, p 552 http://dx.doi.org/10.1007/978-3-662-05748-3

37. HAMMER $\varnothing$, HARPERD A T, RYAN P D 2001 PAST: Paleontological statistics software package for education and data analysis. Palaeontol Electron 4: 1-9

38. DEN BOER P J 1981On the survival of populations in a heterogeneous and variable environment. Oecologia (Berl) 50: 39-53 http://dx.doi.org/10.1007/BF00378792

39. DEN BOER PJ 1990 The survival value of dispersal in terrestrial Arthropods. Biol Conserv 54: 175-192 http://dx.doi.org/10.1016/0006-3207(90)90050-Y

40. KITAHARA M, SE, K, FUJII K 2000 Patterns in the structure of grassland butterfly communities along a gradient of human disturbance: further analysis based on the generalist/specialist concept. Popul Ecol 42: 135-144 http://dx.doi.org/10.1007/PL00011992 
41. MAYR S, WOLTERS V, DAUBER J 2007 Ground beetles (Coleoptera: Carabidae) in anthropogenic grasslands in Germany: effects of management, habitat and landscape on diversity and community composition. Wiad entomol 26: 169-184

42. MAZALOVÁ M, ŠIPOŠ J, RADA S, KAŠÁK J, ŠARAPATKA B, KURAS T 2015 Responses of grassland arthropods to various biodiversity-friendly management practices: Is there a compromise?
Eur J Entomol 112: 734-746

http://dx.doi.org/10.14411/eje.2015.076

43. KOSEWSKA A, SKALSKI T, NIETUPSKI M 2014 Effects of conventional and non-inversion tillage systems on the abundance and some life history traits of carabid beetles (Coleoptera: Carabidae) in winter triticale fields. Eur J Entomol 111: 669-676 http://dx.doi.org/10.14411/eje.2014.078

\section{APPENDIX 1: LIST OF COLLECTED SPECIES (IN ALPHABETICAL ORDER)}

Agonum gracilipes (Duftschmid, 1812)

Amara aenea (De Geer, 1774)

Amara bifrons (Gyllenhal, 1810)

Amara communis (Panzer, 1797)

Amara convexior Stephens, 1828

Amara curta Dejean, 1828

Amara familiaris (Duftschmid, 1812)

Amara lunicollis Schiödte, 1837

Amara ovata (Fabricius, 1792)

Amara plebeja (Gyllenhal, 1810)

Amara spreta Dejean, 1831

Amara tibialis (Paykull, 1798)

Anisodactylus nemorivagus (Duftschmid, 1812)

Calathus erratus (C.R. Sahlberg, 1827)

Calathus fuscipes (Goeze, 1777)

Calathus melanocephalus (Linné, 1758)

Carabus granulatus Linné, 1758

Cychrus caraboides (Linné, 1758)

Cymindis angularis Gyllenhal, 1810

Harpalus affinis (Schrank, 1781)

Harpalus anxius (Duftschmid, 1812)

Harpalus griseus (Panzer, 1796)

Harpalus latus (Linné, 1758)

Harpalus luteicornis (Duftschmid, 1812)

Harpalus pumilus Sturm, 1818

Harpalus rubripes (Duftschmid, 1812)

Harpalus rufipalpis Sturm, 1818

Harpalus rufipes (De Geer, 1774)

Harpalus smaragdinus (Duftschmid, 1812)

Harpalus tardus (Panzer, 1796)

Panagaeus bipustulatus (Fabricius, 1775)

Poecilus cupreus (Linné, 1758)

Poecilus lepidus (Leske, 1785)

Poecilus versicolor (Sturm, 1824)

Pterostichus melanarius (Illiger, 1798)

Pterostichus niger (Schaller, 1783)

Pterostichus oblongopunctatus (Fabricius, 1787)

Syntomus truncatellus (Linné, 1761)

Synuchus vivalis (Illiger, 1798)

Zabrus tenebrioides (Goeze, 1777) 
